\title{
Penyusunan Kurikulum Perguruan Tinggi Keagamaan Kristen Mengacu pada Kerangka Kualifikasi Nasional Indonesia
}

\author{
Markus Oci \\ STT Kanaan Nusantara Ungaran \\ Korespondensi:markus.oci@gmail.com \\ Kalis Stevanus \\ STT Tawangmangu \\ kalisstevanus91@gmail.com
}

\begin{abstract}
The rapid development of Science and Technology in the era of the Industrial Revolution 4.0 has influenced various aspects of human life, both in the world of work and the world of education. The purpose of this article is written with the hope that Christian Religious Colleges can answer the challenges of the Industrial Revolution 4.0 in order to produce human resources or graduates who are able to compete in the midst of global competition. One of the steps is to reconstruct a curriculum that is responsive to technological developments. The compilation and implementation of curricula at Christian Religious Colleges must refer to KKNI and the National Higher Education Standards. The research method used is qualitative research with a literature study approach. The analysis process carried out is to use various literary sources, both journals, books and other reliable reference materials to support the author's analysis. Thus it can be concluded that there are six steps in the preparation of the curriculum for Christian Religious Higher Education which refers to the Indonesian National Qualifications Framework (KKNI): 1. Formulating a Graduate Profile; 2. Formulating Graduate Learning Outcomes; 3. Determine the Study Material; 4. Compiling Subjects; 5. Determining the Structure of the Course and, 6. Developing a semester learning plan (RPS).
\end{abstract}

Keywords: curriculum, higher education, kkni

\begin{abstract}
Abstrak
Derasnya perkembangan Ilmu Pengetahuan dan Teknologi di era Revolusi Industri 4.0 telah mempengaruhi pelbagai aspek kehidupan manusia, baik di dunia kerja maupun dunia pendidikan. Tujuan artikel ini ditulis dengan harapan Perguruan Tinggi Keagamaan Kristen dapat menjawab tantangan Revolusi Industri 4.0 guna menghasilkan sumber daya manusia atau lulusan yang mampu bersaing di tengah persaingan global. Salah satu langkahnya adalah merekonstruksi kurikulum yang responsif terhadap perkembangan teknologi. Penyusunan dan pelaksanaan kurikulum di Perguruan Tinggi Keagamaan Kristen wajib mengacu pada KKNI dan Standar Nasional Pendidikan Tinggi. Metode penelitian yang digunakan adalah penelitian kualitatif dengan pendekatan studi pustaka. Proses analisis yang dilakukan adalah menggunakan berbagai sumber literatur-literatur baik jurnal, buku dan bahan referensi lainnya yang terpercaya untuk mendukung analisis penulis. Dengan demikian dapat disimpulkan ada enam langkah dalam penyusunan kurikulum Perguruan Tinggi Keagamaan Kristen yang mengacu pada Kerangka Kualifikasi Nasional Indonesia (KKNI): 1. Merumuskan Profil Lulusan; 2. Merumuskan Capaian Pembelajaran Lulusan; 3. Menentukan Bahan Kajian; 4. Menyusun Matakuliah; 5. Menetapkan Struktur Matakuliah dan, 6. Menyusun Rencana pembelajaran semester (RPS).
\end{abstract}

Kata Kunci: kurikulum, perguruan tinggi, kkni 


\section{Pendahuluan}

Perguruan Tinggi Keagamaan Kristen merupakan lembaga formal yang diharapkan dapat melahirkan lulusan atau Sumber Daya Manusia (SDM) yang kompeten dan siap menghadapi lajunya perkembangan dunia kerja yang kian berkembang pesat seiring dengan kemajuan Ilmu Pengetahuan dan Teknologi (IPTEK). Kini, Indonesia telah memasuki Revolusi Industri 4.0. Sehingga Perguruan Tinggi dituntut untuk dapat menjawab tantangan menghadapi kemajuan teknologi dan persaingan dunia kerja di era globalisasi. Tak ketinggalan pula, Perguruan Tinggi Keagamaan Kristen harus mempersiapkan Sumber Daya Manusia (SDM) yang terampil dan andal dalam memasuki era Revolusi Industri 4.0 dan diharapkan mampu menghasilkan lulusan Sumber Daya Manusia (SDM) yang terampil yang mencakup aspek literasi data, literasi teknologi dan literasi manusia yang berakhlak mulia sesuai keyakinan atau keagamaan. ${ }^{1}$ Oleh karna itu kurikulum pendidikan tinggi merupakan program untuk menghasilkan lulusan, sehingga program tersebut seharusnya menjamin agar lulusannya memiliki kualifikasi yang setara dengan kualifikasi yang disepakati dalam Kerangka Kualifikasi Nasional Indonesia (KKNI).

Amanat Undang-Undang Nomor 12 Tahun 2012 Pasal 35 ayat 2 tentang kurikulum menyebutkan bahwa Kurikulum Pendidikan Tinggi dikembangkan oleh setiap Perguruan Tinggi dengan mengacu pada Standar Nasional Pendidikan Tinggi untuk setiap Program Studi yang mencakup pengembangan kecerdasan intelektual, akhlak mulia, dan keterampilan. Standar Nasional Pendidikan Tinggi (SN-DIKTI), sebagaimana diatur dalam Permenristekdikti Nomor 44 Tahun 2015 Pasal 1, menyatakan kurikulum adalah seperangkat rencana dan pengaturan mengenai capaian pembelajaran lulusan, bahan kajian, proses, dan penilaian yang digunakan sebagai pedoman penyelenggaraan program studi. ${ }^{2}$

Konsep kurikulum yang dikembangkan Direktorat Jenderal Pembelajaran dan Kemahasiswaan selama ini, dalam menyusun kurikulum dimulai dengan menetapkan profil lulusan yang dijabarkan menjadi rumusan capaian pembelajaran lulusan. Rumusan kemampuan yang pada deskriptor Kerangka Kualifikasi Nasional Iinfonesia (KKNI) dinyatakan dengan istilah capaian pembelajaran (terjemahan dari learning outcomes), dimana kompetensi tercakup di dalamnya atau merupakan bagian dari capaian pembelajaran $(\mathrm{CP}) .{ }^{3}$ Rumusan kurikulum yang berkualitas memiliki pengaruh signifikan terhadap kualitas pendidikan sehingga diharapkan dapat meningkatkan mutu lulusan agar dapat bersaing di pasar global. ${ }^{4}$

Menurut Tim Penyusunan Panduan Pengembangan Kurikulum PTKI Mengacu pada KKNI dan SNPT, menjelaskan bahwa Kerangka Kualifikasi Nasional Indonseia, selanjutnya disebut KKNI, disusun sebagai respons dari ratifikasi Indonesia tahun 2007 terhadap konvensi UNESCO tentang pengakuan pendidikan diploma dan pendidikan tinggi (the International Convention on the Recognition of Studies, Diplomas and Degrees in Higher Education in Asia and the Pasific) yang disahkan pada tanggal 16 Desember 1983 dan diperbaharui tanggal 30 Januari 2008. KKNI tersebut berguna untuk melakukan penilaian kesetaraan capaian pembelajaran serta kualifikasi tenaga kerja baik yang akan belajar atau bekerja di Indonesia ataupun ke luar negeri. Dengan kata lain, KKNI menjadi acuan mutu pendidikan Indonesia ketika disandingkan dengan pendidikan bangsa lain. Lulusan pendidikan tinggi

1 Tim Penyusunan Buku Panduan Penyusunan Kurikulum Pendidikan Tinggi di Era Industri 4.0. (Jakarta: Direktorat Pembelajaran Jenderal Pembelajaran Dan Kemahasiswaan Kementerian Riset, Teknologi Dan Pendidikan Tinggi, 2019). 8.

2 Permenristekdikti Nomor 44 Tahun 2015 Tentang Standar Nasional Pendidikan Tinggi. 4.

3 Ibid.,

4 Lailial Muhtifah, dkk, Sturktur Kurikulum Berbasis Kerangka Kualifikasi Nasionali Indonesia (KKNI) Dan Standar Nasional Perguruan Tinggi (SN-PT). Pontianak: PAI IAIN, 2017. 4. 
Indonesia dapat disejajarkan denga lulusan pendidikan di luar negeri melalui skema KKNI. Di lain pihak, lulusan luar negeri yang akan masuk ke Indonesia dapat pula disejajarkan capaian pembelajarannya dengan KKNI yang dimiliki Indonesia. ${ }^{5}$

Sedangkan menurut Nurhadi Agung Setiyawan, menguraikan bahwa pengembangan Ilmu Pengetahuan dan Teknologi, Seni (IPTEKS) terasa semakin pesat, juga persaingan ketersedian lapangan kerja semakin ketat pula. Oleh karena itu, di era persaingan global ini, menuntut perlunya dilakukan kembali kajian atau review kurikulum di Indonesia, tentunya termasuk kurikulum yang ada di Jurusan Pendidikan Bahasa Arab Fakultas Ilmu Tarbiyah dan Keguruan Universitas Islam Negeri Sunan Kalijaga Yogyakarta. Sejalan dengan hal tersebut, Universitas Islam Negeri Sunan Kalijaga Yogyakarta telah melakukan workshop kurikulum pada awal November 2015 berkenan dengan adanya rencana memberlakukan kurikulum berbasis Kerangka Kualifikasi Nasional Indonesia (KKNI) pada kurikulum program studi yang ada di UIN Sunan Kalijaga Yogyakarta, termasuk di Jurusan Pendidikan Bahasa Arab. Penekanan ini adalah memberi ciri atau bobot bahwa setiap lulusan harus memiliki standar kompetensi lulusan yang dapat dimanfaatkan dan relevan dengan lapangan kerja yang tersedia, yakni selain memiliki kompetensi utama, juga memiliki kompetensi pendukung dan pelengkap, sehingga lulusan tersebut memiliki daya saing tinggi dan luas dalam menghadapi dunia kerja baik secara nasional maupun internasional. Dengan demikian output penelitian ini mengacu pada tingkat relevansi capaian pembelajaran dalam kurikulum Jurusan Pendidikan Bahasa Arab dengan lapangan kerja yang tersedia. ${ }^{6}$

Berdasarkan beberapa uraian di atas tentang penyusunan kurikulum mengacu kepada kerangka kualifikasi Indoneisa (KKNI) adalah suatu keharusnya diterapkan di setiap perguruan tinggi, dalam konteks Perguruan Tinggi Keagamaan Kristen adalah rekonstruksi kurikulum yang responsif terhadap Revolusi Industri 4.0, yaitu mesti terus berbenah diri dengan mengubah kurikulum dan proses pendidikan yang selama ini diterapkan. Sebab bila tidak berbenah diri guna mengantisipasi perubahan yang sangat cepat ini dan beradaptasi terhadap perubahan itu sendiri dengan melakukan perubahan termasuk kurikulum dan proses pendidikan, maka Perguruan Tinggi Keagamaan Kristen akan ketinggalan. Sebenarnya perubahan kurikulum di Perguruan Tinggi termasuk di Perguruan Tinggi Keagamaan Kristen mestinya dijadikan sebagai aktivitas rutin yang harus dilakukan sebagai respon terhadap perkembangan Ilmu Pengetahuan dan Teknologi (IPTEK) dan kebutuhan pengguna lulusan (stakeholder).

Kurikulum bukanlah sesuatu yang permanen tapi bersifat fleksibel dan dinamis. Kurikulum yang dikembangkan di Perguruan Tinggi Keagamaan Kristen bukan sesuatu yang sakral tidak bisa diubah-menjadi dogma. Sebaliknya, pengembangan kurikulum Perguruan Tinggi Keagamaan Kristen perlu beradaptasi dengan perkembangan Ilmu Pengetahuan dan Teknologi (IPTEK) dengan melakukan evaluasi diri secara berkala. Perguruan Tinggi Keagamaan Kristen dalam menyusun atau mengembangkan kurikulum, wajib mengacu pada Kerangka Kualifikasi Nasional Indonesia (KKNI) dan Standar Nasional Pendidikan Tinggi. Tantangan yang dihadapi oleh Perguruan Tinggi Keagamaan Kristen dalam pengembangan kurikulum di era Revolusi Industri 4.0 adalah menghasilkan lulusan

5 Tim Penyusunan Panduan Pengembangan Kurikulum PTKI Mengacu pada KKNI dan SNPT (Jakarta: Direktorat Pendidikan Tinggi Keagamaan Islam Direktorat Jenderal Pendidikan Islam Kementerian Agama Republik, 2018) 1.

6 Nurhadi Agung Setiyawan, Model Penerapan Kerangka Kualifikasi Nasional Indonesia (KKNI) Sebagai Penguatan Mutu Program Studi Pendidikan Bahasa Arab. Yogyakarta, Al Mahara Jurnal Pendidikan Bahasa Arab, Vol.3, No.2, Desember 2017. 3. 
yang memiliki kemampuan literasi baru meliputi literasi data, literasi teknologi, dan literasi manusia yang berakhlak mulia sesuai keyakinan atau kagamaan. ${ }^{7}$

Kurikulum Perguruan Tinggi Keagamaan Kristen merupakan mandat institusi yang harus senantiasa diperbaharui, yakni bersifat fleksibel dan dinamis sesuai dengan perkembangan kebutuhan pengguna lulusan (stakeholders) dan IPTEK yang dituangkan dalam Capaian Pembelajaran (CP). Perguruan Tinggi Keagamaan Kristen sebagai penghasil Sumber Daya Manusia (SDM) terdidik perlu mengukur lulusannya, apakah lulusan yang dihasilkan memiliki kemampuan setara dengan kemampuan yang dituangkan dalam Capaian Pembelajaran (CP) yang telah dirumuskan dalam jenjang kualifikasi Kerangka Kualifikasi Nasional Indonesia (KKNI). Perguruan Tinggi Keagamaan Kristen wajib menyesuaikan diri dengan ketentuan tersebut.

\section{Metode Penelitian}

Metode penelitian yang penulis gunakan dalam penelitian ini adalah penelitian kualitatif (qualitative research), dengan pendekatan studi pustaka. Yang dimaksudkan dengan studi pustaka (library research) di sini adalah kegiatan penulis untuk menghimpun informasi yang relevan dengan topik atau masalah yang menjadi obyek penelitian. ${ }^{8}$ Penulis mengadakan penyelidikan buku-buku atau literatur yang berkaitan dengan pembahasan Penyusunan Kurikulum Perguruan Tinggi Keagamaan Kristen Kepadaa Mengacu Kepada Kerangka Kualifikasi Nasional Indonesia (KKNI). Studi pustaka (library research) ini dengan tujuan untuk mengenali teori atau konsep yang diketemukan oleh para ahli terdahulu dan memperoleh orientasi yang lebih luas mengenai topik yang penulis teliti sebagai referensi dalam penelitian ini. Dari berbagai informasi yang diperoleh dari beberapa literatur tersebut, kemudian penulis mensintesakan yang akhirnya menjadi kesimpulan. Kesimpulan tersebut kemudian disusun secara logis dan sistematis deskriptis untuk menjawab pokok permasalahan dalam penelitian ini.

\section{Hasil dan Pembahasan \\ Pengertian Kurikulum}

Kurikulum memegang peranan yang sangat penting dalam kegiatan proses belajar belajar atau pembelajaran. Dengan adanya kurikulum tersebut berarti satuan pendidikan atau lembaga pendidikan memiliki panduan dalam kegiatan belajar mengajar. Secara etimologi "kurikulum" berasal dari bahasa Latin curriculumyang terdiri dari dua kata kerja, kata curir yang berarti : pelari, sedangkan katacurere berarti: tempat berpacu. Istilah ini berasal dari dunia olah raga, pada zaman Romawi Kuno. ${ }^{9}$ Dapat dibahasakan lain, kurikulum adalah sesuatu jarak yang harus ditempuh oleh seseorang pelari dari garis start sampai dengan garis finish. Kurikulum dipandang sebagai suatu rencana yang disusun untuk melancarkan proses belajar mengajar dibawah bimbingan dan tanggungjawab sekolah atau lembaga pendidikan beserta staff pengajarnya. ${ }^{10}$

Kurikulum merupakan seperangkat rencana dan pengatur mengenai tujuan, isi, dan bahan pelajaran serta cara yang digunakan sebagai tujuan pedoman penyelenggaraan kegiatan pembelajaran untuk mencapai tujuan pendidikan tertentu. ${ }^{11}$ Hal yang sama dikemukakan oleh Mulyasa, kurikulum dapat didefinisikan adalah seperangkat rencana dan

${ }^{7}$ Loc. Cit., 1.

8Stefanus M. Marbun, Kalis Stevanus," Pendidikan Seks Pada Remaja" FIDEI: Jurnal Teologi Sistematika Dan Praktika, Vol.2, No.2, Desember 2019: 328

${ }^{9}$ Oemar Hamalik, Kurikulum dan Pembelajaran. (Jakarta : Bumi Askara, 2008) 16.

10 S. Nasution. Kurikulum dan Pengajaran. (Jakarta : Bumi Askara, 2006) 6.

${ }^{11}$ Undang-Undang Nomor 20 Tahun 2003 Tentang Sistem Pendidikan Nasional. 3. 
pengatur mengenai tujuan kompetensi dasar, materi standar, serta cara yang digunakan sebagai pedoman penyelenggara kegiatan pembelajaran untuk mencapai kompetensi dasar dan tujuan pendidikan. ${ }^{12}$

Kurikulum adalah suatu program pendidikan yang berisikan berbagai bahan ajar dan pengalaman belajar yang diprogramkan, direncanakan dan dirancang berdasarkan asas, norma yang berlaku kemudian menjadi pedoman dalam kegiatan belajar mengajar. UndangUndang Nomor 12 Tahun 2012 Tentang Pendidikan, menjelaskan definisi tentang Kurikulum Perguruan Tinggi, sebagai berikut: (1) kurikulum pendidikan tinggi merupakan seperangkat rencana dan pengatur mengenai tujuan, isi, dan bahan ajar seta cara yang digunakan sebagai pedoman penyelenggaraan kegiatan pembelajaran untuk mencapai tujuan Pendidikan Tinggi, dan (2) Kurikulum pendidikanTinggi sebagaimana dimaksud pada ayat (1) dikembangkan oleh setiap Perguruan Tinggi dengan mengacu pada standar Nasional Pendidikan Tinggi untuk setiap Program Studi yang mencakup pengembangan keserdasaan, akhlak, dan keterampilan. ${ }^{13}$

Meminjam penjelasan Kurikulum Pendidikan Tinggi Keagamaan yang dituangkan di Peraturan Presiden Nomor 46 Tahun 2019 Tentang Pendidikan Keagamaan, adalah memuat seperangkat rencana dan pengaturan mengenai tujuan, isi, dan bahan ajar serta cara yang digunakan sebagai pedoman penyelenggaraan kegiatan pembelajaran untuk mencapai tujuan Pendidikan Tinggi Keagamaan. ${ }^{14}$ Dari penjelasan ini, dapat dikatakan Kurikulum Perguruan Tinggi Keagamaan Kristen adalah Sebagai seperangkat dan pengatur kegiatan belajar mengajar atau pembelajaran kurikulum Perguruan Tinggi Keagamaan menjadi panduan atau acuan. Di dalam kurikulum tersebut menyangkut materi, cara pendidikan dan cara penilaian.

Kurikulum Pendidikan Keagamaan Kristen pada prinsipnya dikembangkan oleh setiap satuan pendidikan. Artinya dalam pengembangan kurikulum Pendidikan Keagamaan Kristen berdasarkan pada institusi atau Program Studi di Perguruan Tinggi Keagamaan Kristen tersebut. Kurikulum Perguruan Tinggi Keagamaan Kristen mencakup seluruh kegiatan belajar mengajar atau pembelajaran dan aktivitas Perguruan Tinggi Keagamaan Kristen tersebut. Seluruh aktivitas pada Perguruan Tinggi Keagamaan Kristen yang maksud adalah kegiatan akademik dan non akademik.

\section{Dasar Hukum Penyusunan dan Pelaksanaan Kurikulum Perguruan Tinggi}

Berikut adalah beberapa landasan hukum yang diperlukan dalam penyusunan dan pelaksanaan kurikulum: 15

1. Undang-Undang Republik Indonesia Nomor 14 Tahun 2005 tentang Guru dan Dosen (Lembaran Negara Republik Indonesia Tahun 2005 Nomor 157, Tambahan Lembaran Negara Republik Indonesia Nomor 4586);

${ }^{12}$ H.E.Mulyasa, Implementasi Kurikulum Tingkat Satuan Pendidikan (Jakarta: Bumi Askara, 2010)

22.

${ }^{13}$ Undang-Undang Nomor 12 Tahun 2012 Tentang Pendidikan Tinggi. 26.

${ }^{14}$ Peraturan Presiden Nomor 46 Tahun 2019 Tentang Pendidikan Keagamaan. 17

${ }^{15}$ Tim Penyusun, Panduan Penyusunan Kurikulum Pendidikan Tinggi di Era Industri 4.0. (Jakarta: Direktorat Pembelajaran Dan Kemahasiswaan, Kementerian Riset, Teknologi Dan Pendidikan Tinggi, 2019), 11-12 
2. Undang-Undang Republik Indonesia Nomor 12 Tahun 2012 tentang Pendidikan Tinggi (Lembaran Negara Republik Indonesia Tahun 2012 Nomor 158, Tambahan Lembaran Negara Republik Indonesia Nomor 5336);

3. Peraturan Presiden Republik Indonesia Nomor 8 Tahun 2012, Tentang Kerangka Kualifikasi Nasional Indonesia (KKNI);

4. Peraturan Menteri Pendidikan dan Kebudayaan Republik Indonesia Nomor 73 Tahun 2013, Tentang Penerapan KKNI Bidang Perguruan Tinggi;

5. Peraturan Menteri Riset, Teknologi, dan Pendidikan Tinggi Republik Indonesia Nomor 44 Tahun 2015, Tentang Standar Nasional Pendidikan Tinggi;

6. Peraturan Menteri Pendidikan dan Kebudayaan Republik Indonesia Nomor 81 Tahun 2014, Tentang Ijazah, Sertifikat Kompetensi, Dan Sertifikat Profesi Pendidikan Tinggi;

7. Peraturan Menteri Riset, Teknologi, dan Pendidikan Tinggi Republik Indonesia Nomor 32 Tahun 2016, Tentang Akreditasi Program Studi dan Perguruan Tinggi;

8. Peraturan Menteri Riset, Teknologi, dan Pendidikan Tinggi Republik Indonesia Nomor 62 Tahun 2016 Tentang Sistem Penjaminan Mutu Pendidikan Tinggi;

9. Peraturan Menteri Riset, Teknologi, dan Pendidikan Tinggi Republik Indonesia Nomor 13 Tahun 2015 Tentang Rencana Strategis Kementerian Riset, Teknologi, Dan Pendidikan Tinggi Tahun 2015-2019;

10. Peraturan Menteri Riset, Teknologi, dan Pendidikan Tinggi Republik Indonesia Nomor 55 Tahun 2017 Tentang Pendidikan Standar Guru.

\section{Dasar Hukum Penyusunan Kurikulum Mengacu Pada Kerangka Kualifikasi Nasional Indonesia (KKNI)}

Diterbitkannya Peraturan Presiden Nomor 8 Tahun 2012 tentang Kerangka Kualifikasi NasionalIndonesia (KKNI), dan Undang-Undang Nomor 12 Tahun 2012 tentang Pendidikan Tinggi, mendorong semua perguruan tinggi termasuk Perguruan Tinggi Keagamaan Kristen untuk menyesuaikan diri dengan ketentuan tersebut. KKNI merupakan pernyataan kualitas sumber daya manusia Indonesia yang penjenjangan kualifikasinya didasarkan pada tingkat kemampuan yang dinyatakan dalam rumusan capaian pembelajaran (learning outcomes). Perguruan tinggi sebagai penghasil sumber daya manusia terdidik perlu mengukur lulusannya, apakah lulusan yang dihasilkan memiliki kemampuan setara dengan kemampuan (capaian pembelajaran) yang telah dirumuskan dalam jenjang kualifikasi KKNI. Dan telah ditetapkan secara nasional bahwa lulusan program sarjana paling rendah harus memiliki "kemampuan" yang setara dengan "capaian pembelajaran" yang dirumuskan pada jenjang 6 KKNI, Magister setara jenjang 8, dan doktor setara jenjang9. Perguruan tinggi dalam menyusun atau mengembangkan kurikulum, wajib mengacu pada KKNI dan Standar Nasional Pendidikan Tinggi. ${ }^{16}$

Sebagaimana yang diamanatkanUndang-Undang Nomor 12 Tahun 2012 tentang Pendidikan Tinggibahwa penyusunan kurikulum adalah hak perguruan tinggi, tetapi selanjutnya dinyatakan harus mengacu kepada standar nasional (Pasal 35 ayat (1). Dasar hukum penyusunan Kurikulum Perguruan Tinggi Keagamaan Kristen, mengacu kepada Undang-Undang Nomor 12 Tahun 2012 tentang Pendidikan Tinggi, pada Bagian Kelima tentang Kerangka Kualifikasi Nasional, pasal 29 ayat 1 dan 2, sebagai berikut:

${ }^{16}$ Tim Penyusun, Panduan Penyusunan Kurikulum Pendidikan Tinggi di Era Industri 4.0. (Jakarta: Direktorat Pembelajaran Dan Kemahasiswaan, Kementerian Riset, Teknologi Dan Pendidikan Tinggi, 2019), 8 
1. Kerangka Kualifikasi Nasional merupakan penjenjangan capaian pembelajaran yang menyetarakan luaran bidang pendidikan formal, nonformal, informal, atau pengalaman kerja dalam rangka pengakuan kompetensi kerja sesuai dengan struktur pekerjaan diberbagai sektor.

2. Kerangka Kualifikasi Nasional sebagaimana dimaksud pada ayat (1) menjadi acuan pokok dalam penetapan kompetensi lulusan pendidikan akademik, pendidikan vokasi, dan pendidikan profesi. ${ }^{17}$

Juga dijelaskan pada Peraturan Presiden Nomo 8 tahun 2012 Tentang Kerangka Kualifikasi Nasional Pendidikan pada Bab I Ketentuan Umum Pasal 1 ayat 1, 2, 3, dan 4, menjelaskan :

1. Kerangka Kualifikasi Nasional Indonesia, yang selanjutnya disingkat KKNI, adalah kerangka penjenjangan kualifikasi kompetensi yang dapat menyandingkan, menyetarakan, dan mengintegrasikan antara bidang pendidikan dan bidang pelatihan kerja serta pengalaman kerja dalam rangka pemberian pengakuan kompetensi kerja sesuai dengan struktur pekerjaan di berbagai sektor.

2. Capaian pembelajaran adalah kemampuan yang diperoleh melalui internalisasi pengetahuan, sikap, ketrampilan, kompetensi, dan akumulasi pengalaman kerja.

3. Penyetaraan adalah proses penyandingan dan pengintegrasian capaian pembelajaran yang diperoleh melalui pendidikan, pelatihan kerja, dan pengalaman kerja.

4. Kualifikasi adalah penguasaan capaian pembelajaran yang menyatakan kedudukannya dalam KKNI.18

Sebagaimana diharapkan oleh Basani bahwa kurikulum perguruan tinggi yang sudah merupakan kurikulum nasional berbasis kompetensi yang diselaraskan dengan Kerangka Kualifikasi Nasional Indonesia (KKNI) maka manusia Indonesia dapat memenuhi kualifikasi yang dibutuhkan dalam dunia kerja. Lulusan perguruan tinggi tidak hanya memperhatikan lulusan yang mempunyai kemampuan secara hard skill tapi secara softskillnya menjadi lulusan yang berkemampuan tidak hanya secara keilmuan tapi lulusan betulbetul mengerti tujuan akhir dari proses pendidikannya sehingga menjadi lulusan yang bertanggung jawab pada profesinya. ${ }^{19}$

Dengan demikian, dapat disimpulkan bahwa Kerangka Kualifikasi Nasional yang disingkat menjadi KKNI adalah suatu keharusan untuk menerapkannya di setiap jenjang pendidikan Perguruan Tinggi termasuk Perguruan Tinggi Keagamaan Kristen di dalamnya. Acuan tersebut digunakan dalam menetapkan kompetensi lulusan yang mencakup pendidikan akademik, pendidikan vokasi dan pendidikan profesi.

\section{Tahapan Penyusunan Kurikulum Perguruan Tinggi Keagamaan Kristen}

Tahapan dalam penyusunan Kurikulum Perguruan Keagamaan Kristen adalah tahapan-tahapan yang dilaksanakan oleh setiap Terguruan Tinggi dan Program studi untuk mendapatkan hasil yang maksimal. Kurikulum merupakan seperangkat rencana dan

17 Peraturan Presiden Nomor 46 Tahun 2019 Tentang Pendidikan Keagamaan, 24

3.

18 Peraturan Presiden Nomo 8 Tahun 2012 Tentang Kerangka Kualifikasi Nasional Indonesia.

19 Christin Septina Basani, Kurikulum Nasional Yang Berbasis Kompetensi Perguruan Tinggi Dengan Mengacu Pada Kreangka Kualifikasi Nasional Indonesia (KKNI) Untuk Menghasilkan Kualitas Manusia Yang Kompetensi dan Berdaya Saing. Bandung: Jurnal Dialogia Luridica, Vol. 7, No 1, November 2015. 65. 
pengaturan mengenai capaian pembelajaran lulusan, bahan kajian, proses, dan penilaian yang digunakan sebagai pedoman penyelenggaraan program studi. Tahapan yang dilakukan oleh pengelola program studi dalam menyusun dan mengembangkan kurikulum. ${ }^{20}$

Tahapan ini dimulai dari analisis kebutuhan (market signal) yang menghasilkan profil lulusan, dan kajian-kajian yang dilakukan oleh program studi sesuai dengan disiplin bidang ilmunya (scientific vision) yang menghasilkan bahan kajian. Rumuskan Capaian pembelajaran Lulusan (CPL), mata kuliah beserta bobot sks-nya, dan penyusunan organisasi mata kuliah dalam bentuk matrik. Tahapan-tahapan dalam penyusunan Kurikulum Perguruan Tinggi Keagamaan harus dipersiapkan dengan sebaik-baiknya agar mendapat hasil yang maksimal, artinya produk dari penyusunan Kurikulum Tinggi Keagamaan Kristen sesuai visi, misi dan konteks kekinian (Market Ministry.)

\section{Menentukan Profil Lulusan}

Penetapan Profil Lulusan Program Studi Profil lulusan adalah output atau hasil produk yang dihasilkan oleh Program studi yang menunjukkan kepada kekhasan serta mencirikan keunggulan Program Studi dan yang membedakan dengan Program studi yang lain. Profil lulusan menjadi pembeda suatu program studi dengan program studi lainnya. Profil lulusan dinyatakan dengan kata benda yang menunjukan peran dan fungsi lulusan setelah lulus dari suatu program studi, bukan jabatan ataupun jenis pekerjaan. ${ }^{21}$

Profil lulusan adalah peran yang dapat dilakukan oleh lulusan di bidang keahlian atau bidang kerja tertentu setelah menyelesaikan studinya. Seyogyanya profil lulusan program studi disusun oleh kelompok program studi (prodi) sejenis, sehingga terjadi kesepakatan yang dapat diterima dan dijadikan rujukan secara nasional. Profil lulusan setiap program studi disusun oleh kelompok program studi sejenis, sehingga terjadi kesepakatan yang dapat diterima dan dijadikan rujukan secara nasional. Untuk dapat menjalankan peran-peran yang dinyatakan dalam profil tersebut diperlukan "kemampuan" yang harus dimiliki. ${ }^{22}$ Pada prinsipnya Profil Lulusan disetiap program studi adalah keunggulan yang dimiliki disetiap Program Studi yang kemudian diejawantahkan dalam keterampilan mahasiwa (produk) yang dihasilkan. Profil lulusan disetiap Program studi tidak terlepas dari kebijakan Institusi artinya ada kaitan dengan rencana strategi dan rencana operasional di setiap program studi.

Kebijakan institusi atau rencana strategi dan rencana operasional adalah pengejawantahan dari visi dan misi di setiap program studi. Menurut Tim Penyusunan Panduan Pengembangan Kurikulum PTKI Mengacu pada KKNI dan SN-PT.Penyusunan Profil Lulusan dapat mengikuti langkah-langkah berikut: pertama adalah melakukan studi pelacakan (tracer study) kepada pengguna potensial yang sesuai dengan bidang studi, salah satunya dengan mengajukan pertanyaan berikut: berperan sebagai apa sajakah lulusan program studi tertentu? Jawaban dari pertanyaan ini menunjukkan "sinyal kebutuhan pasar" (market signal), kedua, adalah mengidentifikasi peran lulusan berdasarkan tujuan diselenggarakannya program studi sesuai dengan visi dan misi, ketiga adalah membuat kesepakatan antar program studi yang sama sehingga ada penciri umum program studi. ${ }^{23}$

20Panduan Pengembangan Kurikulum PTKI Mengacu pada KKNI dan SN-PT. (Jakarta : Direktorat Pendidikan Tinggi Agama Islam, Kementerian Agama Islam, 2008).10.

${ }^{21}$ Panduan Pengembangan Kurikulum PTKI Mengacu pada KKNI dan SNPT. (Jakarta : Direktorat Pendidikan Tinggi Agama Islam, Kementerian Agama Islam, 2018),11.

${ }^{22}$ Panduan Penyusunan Kurikulum Perguruan Tinggi. (Jakarta: Direktorat Jendral Pembelajaran

Dan Kemahasiswaan, Kementerian Riset, Tekonologi Dan Pendidikan Tinggi, 2016). 17.

23Ibid., 12. 
Selain kebijakan institusi dalam menentukan profil lulusanan, yakni: masukan dari pengguna (stakeholder) dan hasil studi pelacakan almuni. Hasil studi pelacakan almuni dan masukan pengguna (Stakeholder) minimal tiga tahun setelah kelulusan alumni yang menjadi bahan pertimbangan dalam menentukan profil lulusan perguruan tinggi dan program studi yang ada.

\section{Merumuskan Capaian Pembelajaran Lulusan}

Peraturan Presiden Nomor 08 Tahun 2012 Tentang Pendidikan Tinggi, Bab I Ketentuan Umum pasal 1 ayat 2, mengatakan, "Capaian pembelajaran adalah kemampuan yang diperoleh melalui internalisasi pengetahuan, sikap, ketrampilan, kompetensi, dan akumulasi pengalaman kerja. ${ }^{24}$ Adapun rumusan capaian pembelajaran lulusan (CPL) sebagaimana telah ditetapkan secara nasional pada Peraturan Menteri Riset, Teknologi, Dan Pendidikan Tinggi Republik Indonesia Nomor 44 Tahun 2015 Tentang Standar Nasional Pendidikan Tinggi pada Bab II pasal 5 adalah sebagai berikut: 25

(1)Standar kompetensi lulusan merupakan kriteria minimal tentang kualifikasi kemampuan lulusan yang mencakup sikap, pengetahuan, dan keterampilan yang dinyatakan dalam rumusan capaian pembelajaran lulusan.

(2) Standar kompetensi lulusan yang dinyatakan dalam rumusan capaian pembelajaran lulusan sebagaimana dimaksud pada ayat (1) digunakan sebagai acuan utama pengembangan standar isi pembelajaran, standar proses pembelajaran, standar penilaian pembelajaran, standar dosen dan tenaga kependidikan, standar sarana dan prasarana pembelajaran, standar pengelolaan pembelajaran, dan standar pembiayaan pembelajaran.

(3) Rumusan capaian pembelajaran lulusan sebagaimana dimaksud pada ayat (1) wajib:

a. mengacu kepada deskripsi capaian pembelajaran lulusan KKNI; dan

b. memiliki kesetaraan dengan jenjang kualifikasi pada KKNI.

Adapun capaian pembelajaran lulusan (CPL) dirumuskan dengan mengacu pada jenjang kualifikasi KKNI dan SN-Dikti. Capaian pembelajaran lulusan (CPL) terdiri dari unsur sikap, ketrampilan umum, ketrampilan khusus, dan pengetahuan. Unsur sikap dan keterampilan umum mengacu pada SN-Dikti sebagai standar minimal, yang memungkinkan ditambah oleh program studi untuk memberi ciri lulusan perguruan tingginya. Sedangkan unsur ketrampilan khusus dan pengetahuan dirumuskan dengan mengacu pada deskriptor KKNI sesuai dengan jenjang pendidikannya. ${ }^{26}$

Menurut Peraturan Menteri Pendidikan Dan Kebudayaan Nomor 3 Tahun 2020 Tentang Standar Nasional Pendidikan Tinggi, pada Bagian Kedua Standar Kompetensi Lulusan Pasal 7 ayat 1, 2, 3 dan 4, hal-hal sebagai berikut:

(1) Rumusan sikap dan keterampilan umum sebagai bagian dari capaian pembelajaran lulusan sebagaimana dimaksud dalam Pasal 6 ayat (1) dan ayat (3) huruf a, untuk setiap tingkat program dan jenis Pendidikan Tinggi, tercantum dalam Lampiran yang merupakan bagian yang tidak terpisahkan dari Peraturan Menteri ini.

2

24Peraturan Presiden Nomor 08 Tahun 2012 Tentang Kerangka Kualifikasi Nasional Indonesia.

25 Peraturan Menteri Riset, Teknologi Dan Pendidikan Tinggi Republik Indonesia Nomor 44 Tahun 2015 Tentang Standar Nasional Pendidikan Tinggi.

26 Tim Penyusun, Panduan Penyusunan Kurikulum Pendidikan Tinggi Di Era Industri 4.0. (Jakarta: Direktorat Jendral Pembelajaran Dan Kemahasiswaan, Kementerian Riset, Teknologi dan Pendidikan Tinggi, 2019), 24. 
(2) Rumusan sikap dan keterampilan umum sebagaimana dimaksud pada ayat (1) dapat ditambah oleh Perguruan Tinggi.

(3) Rumusan pengetahuan dan keterampilan khusus sebagai bagian dari capaian pembelajaran lulusan sebagaimana dimaksud dalam Pasal 6 ayat (1) dan ayat (3) huruf b, wajib disusun oleh:

a. forum Program Studi sejenis atau nama lain yang setara; atau

b. pengelola Program Studi dalam hal tidak memiliki forum Program Studi sejenis.

(4) Rumusan sebagaimana dimaksud pada ayat (2) dan ayat (3) yang merupakan satu kesatuan rumusan capaian pembelajaran lulusan diusulkan kepada direktur jenderal terkait sesuai dengan kewenangannya untuk ditetapkan menjadi capaian pembelajaran lulusan. ${ }^{27}$

Berdasarkan asumsi di atas, dapat disimpulkan bahwa: pertama, bidang Sikap merupakan perilaku benar dan berbudaya sebagai hasil dari internalisasi dan aktualisasi nilai dan norma yang tercermin dalam kehidupan spiritual dan sosial melalui proses pembelajaran, pengalaman mahasiswa, penelitian atau pengabdian kepada masyarakat yang terkait pembelajaran. Kedua, bidang Pengetahuan adalah penguasaan konsep, teori, metode, atau falsafah bidang ilmu tertentu secara sistematis yang diperoleh melalui penalaran dalam proses pembelajaran, pengalaman kerja mahasiswa, penelitian atau pengabdian kepada masyarakat yang terkait pembelajaran. Ketiga, bidang Keterampilan Umum adalah yang wajib dimiliki oleh setiap lulusan dalam rangka menjamin kesetaraan kemampuan lulusan sesuai tingkat program dan jenis pendidikan tinggi, dan keempat bidang Keterampilan khusus yang wajib dimiliki oleh setiap lulusan sesuai dengan bidang keilmuan program studi.

Untuk rumusan bidang sikap dan Keterampilan Umum dirumuskan sesuai dengan Standar Nasional Pendidikan Tinggi sedangkan untuk rumusan bidang pengetahuan dan keteramplian khusus dirumuskan oleh bidang ilmu sebidang atau program studi sejenis sesuai dengan penjelasan didalam lampiran Peraturan Presiden Nomor 8 Tahun 2012 Tentang Kerangka Kualifikasi Nasional Indonesia.

\section{Menentukan Bahan Kajian}

Rumusan bahan kajian merupakan rumusan dapat dianalisis berdasarkan unsur pengetahuan dari Capaian Pembelajaran Lulusan yang telah dirumuskan. Unsur pengetahuan ini seyogyanya menggambarkan batas dan lingkup bidang keilmuan atau keahlian yang merupakan rangkaian dari bahan kajian minimal yang harus dikuasai oleh setiap lulusan Program Studi. Bahan kajian adalah adalah turunan dari Capaian Pembelajaran Lulusan (CPL) yang dijabarkan kedalam bidang Ilmu. Menurut Tim Penyusun Panduan Pengembangan Kurikulum PTKI Mengacu pada KKNI dan SN-PT, mengatakan bahwa bahan kajian ini dapat berupa satu atau lebih cabang ilmu beserta ranting ilmunya, atau sekelompok pengetahuan yang telah terintegrasi dalam suatu pengetahuan baru yang sudah disepakati oleh forum Program Studi sejenis sebagai ciri bidang ilmu Program Studi

27Peraturan Menteri Pendidikan Dan Kebudayaan Nomor 03 Tahun 2020 Tentang Standar Nasional Pendidikan Tinggi. 7-8. 
tersebut. Bahan kajian merupakan unsur-unsur keilmuan program studi. Bahan kajian dapat ditentukan berdasarkan struktur isi disiplin ilmu, teknologi, dan seni program studi. ${ }^{28}$

Bahan kajian ini dapat berupa satu atau lebih cabang ilmu beserta ranting ilmunya, atau sekelompok pengetahuan yang telah terintegrasi dalam suatu pengetahuan baru yang sudah disepakati oleh forum prodi sejenis sebagai ciri bidang ilmu prodi tersebut. Dari bahan kajian minimal tersebut, prodi dapat mengurainya Rumusan Capaian Pembelajaran Lulusan (CPL) menjadi lebih rinci tingkat penguasaan, keluasan dan kedalamannya. Bahan kajian dalam kurikulum kemudian menjadi standar isi pembelajaran yang memiliki tingkat kedalam dan keluasan yang mengacu pada Capaian Pembelajaran Lulusan.

Bahan kajian suatu cabang ilmu atau lebih artinya cabang ilmu pengetahuan yang berkaitan dengan keilmuan program studi tertentu. Oleh karena itu bahan kajian juga dapat berupa sistematika bidang keilmuaan tertentu kemudian dijabarkan sampai kepada unsur terkecil dari bidang keilmuan tersebut. Keluasan dan kedalaman bahan kajian merupakan tingkat tercapaian pembelajaran dalam suatu program studi. Dari bahan kajian menjadi lebih rinci menjadi materi pembelajaran atau matakuliah.

\section{Menentukan Matakuliah}

Mata adalah kumpulan dari materi ajar yang terdiri dari bab per-bab atau beberapa pokok pembahasan. Matakuliah Mata kuliah atau modul adalah bungkus dari bahan kajian/materi ajar yang dibangun berdasarkan beberapa pertimbangan saat kurikulum disusun. Mata kuliah dapat dibentuk berdasarkan pertimbangan kemandirian materi sebagai cabang/ranting/bahan kajian bidang keilmuan tertentu atau unit keahlian tertentu (parsial), atau pertimbangan pembelajaran terintergrasi dari sekelompok bahan kajian atau sejumlah keahlian (sistem block) dalam rangka pemenuhancapaian pembelajaran lulusan yang dirumuskan dalam kurikulum.

Sebagai kumpulan, cabang atau ranting dari bahan kajian, matakuliah merupakan penyebutan untuk memudahkan memberi penamaan dalam pelaksanaan pembelajaran. Hubungan matakuliah dengan bahan kajian adalah mencakup bobot Satuan Kredit Semester, keluasan dan kedalaman dalam suatu bahan kajian. Oleh karena itu bobot Satuan Kredit Semester, keluasan dan kedalaman dalam setiap Capaian Pembelajaran pembelajaran termaktum dalam setiap matakuliah.

Dalam menentukan mata kuliah dapat dilakukan dengan mengelompokkan bahan kajian yang setara, kemudian memberikan nama pada kelompok bahan kajian tersebut. Kemudian nama mata kuliah disesuaikan kebiasaan yang dilakukan di program studi. Dalam pemberi penamaan di setiap matakuliah dilakukan oleh kelompok bahan kajian atau program studi sejenis artinya program studi yang satu rumpun dalam keilmuaan tertentu.

\section{Struktur Matakuliah}

Tahapan dalam menyusun struktur matakuliah adalah bentuk organisasi strukur matakuliah yang di implementasi dalam bentuk organisasi matakuliah persemester. Tahap ini adalah menyusun mata kuliah ke dalam semester. Pola susunan mata kuliah perlu

28Panduan Pengembangan Kurikulum PTKI Mengacu pada KKNI dan SNPT. (Jakarta: Direktorat Pendidikan Tinggi Agama Islam, Kementerian Agama Islam, 2018) 21. 
memperhatikan beberapa hal berikut ini. Pertama adalah konsep pembelajaran yang direncanakan dalam usaha memenuhi capaian pembelajaran lulusan; kedua adalah ketepatan letak mata kuliah yang disesuaikan dengan keruntutan tingkat kemampuan dan integrasi antar mata kuliah; ketiga adalah beban belajar mahasiswa rata-rata di setiap semester yakni 18-20 SKS.29 Tahapan penyusunan struktur kurikulum dalam bentuk organisasi matrik mata kuliah per semester perlu memperhatikan hal-hal sebagai berikut:

a. Tahapan pembelajaran mata kuliah yang direncanakan dalam usaha memenuhi capaian pembelajaran lulusan;

b. Ketepatan letak mata kuliah yang disesuaikan dengan keruntutan tingkat kemampuan dan integrasi antar mata kuliah baik secara vertikal maupun horizontal;.

c. Beban belajar mahasiswa secara normal antara 8-10 jam per hari per minggu yang setara dengan beban 17-21 SKS per semester. Proses penyusunannya melibatkan seluruh dosen program studi dan selanjutnya ditetapkan oleh program studi. ${ }^{30}$

Tahapan-tahapan dalam penyusunan struktur matakuliah adalah sistematika bahan kajian yang berdasarkan kelimuan dalam kurikulum tersebut. Organisasi matakuliah dalam struktur adalah bagaimana memastikan tahap-tahapan belajar mahasiswa. Artinya menjamin proses pembelajaran berjalan secara efisien dan efektif guna mencapai capaian pembelajaran lulusan. Dalam pelaksanaan struktur matakuliah yang digunakan terdiri dari organisasi mata kuliah dalam struktur kurikulum terdiri dari organisasi horisontal dan organisasi vertikal. Organisasi mata kuliah horisontal dalam semester dimaksudkan untuk perluasan wacana dan ketrampilan mahasiswa dalam konteks yang lebih luas. Sedangkan organisasi mata kuliah secara vertikal dalam jenjang semester dimaksudkan untuk memberikan kedalam penguasaan kemampuan sesuai dengan tingkat kesulitan belajar untuk mencapai Capaian Pembelajaran Lulusan Program studi yang telah ditetapkan.

\section{Menyusun Rencana Pembelajaran Semester}

Perencanaan proses pembelajaran disusun untuk setiap mata kuliah dan disajikan dalam rencana pembelajaran semester (RPS).Rencana pembelajaran semester (RPS) suatu mata kuliah adalah rencana proses pembelajaran yang disusun untuk kegiatan pembelajaran selama satu semester guna memenuhi capaian pembelajaran lulusan yang dibebankan pada mata kuliah.Rencana pembelajaran semester atau istilah lain, ditetapkan dan dikembangkan oleh dosen secara mandiri atau bersama dalam kelompok keahlian suatu bidang ilmu pengetahuan dan/atau teknologi dalam program studi. ${ }^{31}$ Sebagai pedoman dan acuan dalam kegiatan belajar mengajar Rencana Pembelajaran Semester, disiapkan oleh setiap personal dosen atau berkelompok.

Menurut Peraturan Menteri Pendidikan Dan Kebudayaan Nomor 03 Tahun 2020, menjelaskan tentang Rencana Pembelajaran Semester (RPS), secara mendetail tentang Rencana Pembelajaran Semester, yakni: Rencana Pembelajaran Semester (RPS) atau istilah lain paling sedikit memuat: ${ }^{32}$

${ }^{29}$ Tim Penyusun, Panduan Penyusunan Kurikulum Perguruan Tinggi. (Jakarta: Direktorat Jendral Pembelajaran Dan Kemahasiswaan,Kementerian Riset,Tekonologi Dan Pendidikan Tinggi, 2016 ), 28.

30 Tim Penyusun, Panduan Penyusunan Kurikulum Pendidikan Tinggi Di Era Industri 4.0. (Jakarta: Direktorat Jendral Pembelajaran Dan Kemahasiswaan, Kementerian Riset, Teknologi dan Pendidikan Tinggi, 2019) 29.

31 Tim Penyusun, Panduan Penyusunan Kurikulum Pendidikan Tinggi Di Era Industri 4.0. (Jakarta: Direktorat Jendral Pembelajaran Dan Kemahasiswaan, Kementerian Riset, Teknologi dan Pendidikan Tinggi, 2019), 17.

32 Ibid., 13 
a. Nama Program Studi, nama dan kode mata kuliah, semester, Satuan Kredit Semester, nama Dosen pengampu; \

b. Capaian pembelajaran lulusan yang dibebankan pada mata kuliah;

c. Kemampuan akhir yang direncanakan pada tiap tahap Pembelajaran untuk memenuhi capaian pembelajaran lulusan;

d. Bahan kajian yang terkait dengan kemampuan yang akan dicapai;

e. Metode Pembelajaran;

f. Waktu yang disediakan untuk mencapai kemampuan pada tiap tahap Pembelajaran;

g. Pengalaman belajar mahasiswa yang diwujudkan dalam deskripsi tugas yang harus dikerjakan oleh mahasiswa selama satu semester;

h. Kriteria, indikator, dan bobot penilaian; dan

i. Daftar referensi yang digunakan.

Adapun penyebaran Rencana Pembelajaran Semester (RPS), berdasarkan uraian di atas, sebagai berikut: nama program studi sesuai data yang ada di PDDIKTI. Kode matakuliah sesuai dengan kode yang digunakan di program studi, Semester adalah semester yang sedang berlangsung proses pembelajaran, Satuan Kredit Semester sesuai dengan satuan kredit semester yang sudah disepakati di program studi. Dosen pengampu adalah dosen mengajar matakuliah tersebut, baik secara individu maupun secara tim mengajar (Team Teaching). Bahan Kajian merupakan rincian dari sebuah bahan kajian atau beberapa bahan kajian yang dimiliki oleh mata kuliah terkait. Bahan kajian dapat berasal dari berbagai cabang atau bagian dari bidang keilmuan atau bidang keahlian yang dikembangkan oleh program studi. Materi pembelajaran dapat disajikan dalam bentuk buku ajar, modul ajar, diktat, petunjuk praktikum, modul tutorial, buku referensi, monograf, dan bentuk-bentuk sumber belajar lain yang setara.

Bentuk Pembelajaran adalah metode pembelajaran didasarkan pada keniscayaan bahwa kemampuan yang diharapkan telah ditetapkan dalam suatu tahap pembelajaran sesuai dengan Capaian Pembelajaran Lulusan. Bentuk pembelajaran berupa: kuliah, responsi, tutorial, seminar atau yang setara, praktikum, praktik studio, praktik bengkel, praktik lapangan, penelitian, pengabdian kepada masyarakat. Metode pembelajaran berupa: diskusi kelompok, simulasi, studi kasus, pembelajaran kolaboratif, pembelajaran kooperatif, pembelajaran berbasis proyek, pembelajaran berbasis masalah, atau metode pembelajaran lain, yang dapat secara efektif memfasilitasi pemenuhan capaian pembelajaran lulusan. Waktu merupakan adalah takaran beban belajar mahasiswa yang diperlukan sesuai dengan Capaian Pembelajaran Lulusan yang hendak dicapai.

Pengalaman belajar adalah mahasiswa yang diwujudkan dalam deskripsi tugas yang harus dikerjakan oleh mahasiswa selama satu semester, adalah bentuk kegiatan belajar mahasiswa yang dinyatakan dalam tugas-tugas agar mahasiswa mampu mencapai kemampuan yang diharapkan di setiap tahapan pembelajaran. Proses ini termasuk di dalam. Penilaian mencakup prinsip edukatif, otentik, obyektif, akuntabel, dan transparan yang dilakukan secara terintegrasi.Kriteria menunjuk pada standar keberhasilan mahasiswa dalam sebuah tahapan pembelajaran, sedangkan indikator merupakan unsur-unsur yang menunjukkan kualitas kinerja mahasiswa. Bobot penilaian merupakan ukuran dalam persen (\%) yang menunjukkan persentase penilaian keberhasilan satu tahap belajar terhadap nilai keberhasilan keseluruhan dalam mata kuliah. Daftar Referensi adalah buku atau bentuk lainnya yang dapat digunakan sebagai sumber belajar dalam pembelajaran mata kuliah. 


\section{Implikasi}

Implikasi penelitian ini adalah penyusunan kurikulum perguruan tinggi keagamaan Kristen didalam pelaksanaannya, yakni: Penyusunan Kurikulum Perguruan Tinggi Keagamaan Kristen Mengacu Kepada Kerangka Kualifikasi Nasional Indonesia (KKNI). Hasilnya dapat digunakan sebagai acuan atau pedoman bagi Perguruan Tinggi Keagamaan Kristen dalam menyusun Kurikulum di setiap program studi yang harus mengacu kepada Kerangka Kualifikasi Nasional Indonesia (KKNI).

\section{Rekomendasi untuk Penelitian Lanjutan}

Rekomendasi bagi penelitian lanjutan dalam Penyusunan Kurikulum Perguruan Tinggi Keagamaan yang Mengacu Kepada Kerangka Kualifikasi Nasional Indonesi (KKNI). Diharapkan dapat menambah hal-hal yang belum dijabarkan dalam penelitian ini, sehingga ada pembaharuan (novelty) dalam hal penyusunan kurikulum Perguruan Tinggi Keagamaan Kristen.

\section{Kesimpulan}

Adapun tahapan-tahapan dalam penyusunan Kurikulum Perguruan Tinggi Keagamaan Kristen mengacu kepada Kerangka Kualifikasi Nasional Indonesia (KKNI), sebagai berikut: pertama, Merumuskan Profil Lulusan. Profil lulusan menjadi pembeda program studi tertentu dengan program studi lainnya. Profil lulusan dinyatakan dengan kata benda yang menunjukkan peran dan fungsi lulusan setelah lulus dari suatu program studi, bukan jabatan ataupun jenis pekerjaan. Kedua, Merumuskan Capaian Pembelajaran Lulusan. Capaian pembelajaran lulusan adalah produk (output) yang dihasilkan melalui lulusan di setiap program studi merupakan kemampuan yang dihasilkan dalam Sikap, Pengetahuan, Keterampilan (Umum dan Khusus). Ketiga, Menentukan Bahan Kajian. Bahan Kajian adalah adalah turunan dari Capaian Pembelajaran Lulusan yang dijabarkan kedalam bidang Ilmu. Keempat, Menyusun Matakuliah, matakuliah adalah kumpulan dari materi ajar yang terdiri dari bab per-bab atau beberapa pokok pembahasan. Matakuliah dapat dibentuk atas kumpulan beberapa cabang keilmuan atau ranting-ranting dari dispilin ilmu tertentu. Kelima, Menetapkan Struktur Matakuliah. Struktur matakuliah adalah bentuk organisasi strukur matakuliah yang diimplementasikan dalam bentuk organisasi struktur matakuliah persemester. Keenam, Menyusun Rencana pembelajaran semester (RPS). Rencana pembelajaran semester suatu mata kuliah adalah rencana proses pembelajaran yang disusun untuk kegiatan pembelajaran selama satu semester guna memenuhi capaian pembelajaran lulusan yang dibebankan pada mata kuliah.

\section{Rujukan}

Agung Setiyawan, Nurhadi. "Model Penerapan Kerangka Kualifikasi Nasional Indonesia (KKNI) Sebagai Penguatan Mutu Program Studi Pendidikan Bahasa Arab." Yogyakarta, Al Mahara Jurnal Pendidikan Bahasa Arab, Vol.3, No.2, Desember 2017.

Basani, Christin Septina. "Kurikulum Nasional Yang Berbasis Kompetensi Perguruan Tinggi Dengan Mengacu Pada Kerangka Kualifikasi Nasional Indonesia (KKNI) Untuk Menghasilkan Kualitas Manusia Yang Kompetensi dan Berdaya Saing", Jurnal Dialogia Iuridica, Vol. 7, No 1, November 2015.

Casmin.“Evaluasi Dan Peninjuan Kurikulum BKI Berbasis KKNI”Jurnal Hisbah, Vol. 11, No. 1, Juni 2014.

Hamalik, Oemar. Kurikulum dan Pembelajaran. Jakarta : Bumi Askara, 2010.

Mulyasa, H. E. Implementasi Kurikulum Tingkat Satuan Pendidikan. Jakarta: Bumi Askara, 2010. Marbun,Stefanus M., Kalis Stevanus," Pendidikan Seks Pada Remaja" 
FIDEI: Jurnal Teologi Sistematika Dan Praktika, Vol.2, No.2, Desember 2019

Nasution, S. Kurikulum dan Pengajaran. Jakarta : Bumi Askara, 2006.

Muhtifah, Lailial, dkk, Sturktur Kurikulum Berbasis Kerangka Kualifikasi Nasionali Indonesia (KKNI) Dan Standar Nasional Perguruan Tinggi (SN-PT). Pontianak : PAI IAIN, 2017.

Oci, Markus. “Implikasi Misiologi Dalam Pengembangan Kurikulum Agama Kristen di Gereja Lokal" FIDEI: Jurnal Teologi Sistematika dan Praktika. Vol. 2. Nomor 1, Juni 2019.

Tim Penyusun. Panduan Penyusunan Kurikulum Pendidikan Tinggi di Era Industri 4.0. Jakarta: Direktoral Jendral Pembelajaran, Direktoral Pembelajaran Dan Kemahasiswaan, Kementerian Riset, Teknologi Dan Pendidikan Tinggi, 2019.

Tim Penyusun. Panduan Penyusunan Kurikulum Pendidikan Tinggi. Jakarta: Direktoral Jendral Pembelajaran, Direktoral Pembelajaran Dan Kemahasiswaan, Kementerian Riset, Tekonologi Dan Pendidikan Tinggi, 2016.

Tim Penyusunan. Panduan Pengembangan Kurikulum PTKI Mengacu pada KKNI dan SN-PT. Jakarta: Direktoral Pendidikan Tinggi Agama Islam, Kementerian Agama Islam, 2018.

Tim Penyusunan. Inspirasi Kepemimpinan Era Industri 5.0. Jakarta : Direktoral Jendral Pembelajaran, Direktoral Pembelajaran Dan Kemahasiswaan, Kementerian Riset, Teknologi Dan Pendidikan Tinggi, 2019.

Peraturan Presiden Nomo 8 Tahun 2012 Tentang Kerangka Kualifikasi Nasional Indonesia.

Peraturan Presiden Nomor 46 Tahun 2019 Tentang Pendidikan Keagamaan.

Peraturan Menteri Riset, Teknologi Dan Pendidikan Tinggi Republik Indonesia Nomor 44 Tahun 2015 Standar Nasional Pendidikan Tinggi.

Peraturan Menteri Pendidikan Dan Kebudayaan Nomor 03 Tahun 2020 Tentang Standar Nasional Perguruan Tinggi.

Undang-Undang Nomor 20 Tahun 2003 Tentang Sistem Pendidikan Nasional.

Undang-Undang Repbulik Indonesia Nomor 12 Tahun 2010 Tentang Pendidikan Tinggi.

Agung Setiyawan, Nurhadi. Model Penerapan Kerangka Kualifikasi Nasional Indonesia (KKNI) Sebagai Penguatan Mutu Program Studi Pendidikan Bahasa Arab. Yogyakarta, Al Mahara Jurnal Pendidikan Bahasa Arab, Vol.3, No.2, Desember 2017. 